\title{
PENELITIAN PENGARUH DPT SEBAGAI BLOWING AGENT TERHADAP KETAHANAN KIKIS DAN KEKERASAN SOL KARET
}

\author{
Oleh : Kelompok Peneliti Proses Produksi Barang Karet *)
}

\section{ABSTRACT}

DPT is a blowing agent which is used for the production of soft, medium and hard types of microselluler sole. This type of blowing agent if the rubber compound, will influence the hardness and abrassive resistant of the sole.

Using of 3,5 part blowing agent will give the best quality of rubber compound with the hardness 68,33 shore $A$ and the abrassive resistant $2,60 \mathrm{~mm}^{3} / \mathrm{kgrm}$.

\section{PENDAHULUAN}

\section{Latar Belakang.}

Sol karet merupakan salah satu produksi barang jadi dari bahan baku karet alam yang penggunaannya cukup banyak. Salah satu diantaranya adalah sol luar sepatu. Untuk penggunaan zat pengembang pada pembuatan sol mempunyai keuntungan karena sol dengan karet mikroselluler lebih ringan dari sel yana dibuat tanpa zat pengembang (blowing agent). Keuntungan dari penggunaan blowing agent ini adalah tidak mempengaruhi kecepatan pemasakan. Kelemahan penggunaan karet mikroselluler untuk sol adalah dalam ketahanan kikis dan kekerasan. Untuk itu perlu diadakan penelitian pengaruh blowing agent terhadap ketahanan kikis dan kekerasan dari kompon sol karet. Dalam penelitian ini DPT (Dinitrozo Pentamethylene Tetramine) yana digunakan untuk blowing agent. Hal ini disebabkan karena DPT lebih mudah didapat, lebih murah harganya dan dapat digunakan untuk produk lunak, sedang dan keras.

*) I. Ir. Titien Sayekti Sesantiningsih; 2. Ir. Any Setyaningsih;

3. A. Buchori; 4. HJ. Supardal, BSc; 5. Asrilah, BSc;

6. J. Sagiman; 7. Sri Brataninasih Puji Lestari. 


\section{Tujuan Penelitian :}

- Mencari jumlah blowing agent (DPT) yang optimum untuk pembuatan sol mikroselluler.

Membuat slab mikroselluler.

\section{TINJAUAN PUSTAKA}

\section{Blowing agent :}

Blowing agent adalah zat kimia, anorganik atau organik, dimana dibawah kondisi yang baik, yang telah ditetapkan akan melepaskan gas-gas yang membentuk struktur sol tertutup atau terbuka produk karet.

Blowing agent organik mempunyai beberapa keuntungan diatas blowing agent anorganik. Blowing agent organik adalah kompon nitrogen dimana akan stabil pada penyimpanan normal dan temperatur pencampuran, tetapi perkembangan gas dapat terkontrol pada temperatur dekomposisi yang tepat.

Contoh blowing agent organik adalah :

\section{- DPT (Dinitrozo Pentametylene Tetramine).}

Dikenal sebagai DPT atau DNPT adalah sangat penting dan lebih populer disebut sebagai blowing agent nitrogen digunakan untuk produksi sol mikroselluler jenis lunak, sedang dan keras. Dimana hanya dipanaskan atau ada diluent yang tidak bereaksi dekomposisi secara kimia ini mendekati $195^{\circ} \mathrm{C}$. Dekomposisi dapat dipercepat dan temperatur dapat diperendah sampai $120^{\circ} \mathrm{C}$ dengan substance acidik seperti asam stearat, asam salisilat, asam benzoat dan phtalic anhydride yang umumnya digunakan sebagai bahan pencepat.

DPT menghasilkan volume gas yang besar kira-kira $200 \mathrm{cc}$ per gram dan sangat ekonomis untuk penggunaan barang-barang mikroselluler.

Barang-barang yang dihasilkan dengan DPT mempunyai bau amis (ikan segar) yang mana akan hilang pada penyimpanan. Bau ini dapat dikurangi sedapat mungkin tingkatannya oleh adanya ethylene glycol, asam benzoat dan urea dalam kompon. Blowing agent ini dapat digunakan untuk produksi ebonite yang dikembangkan, DPT adalah non dis - colouring dan non - staining.
A. Bahan dan peralata.1 :

a. Bahan

1. Bahan baku :

- karet alam (Rubber Smoked Sheet / RSS).

- karet sintetik (styrene butadiene rubber / SBR).

2. Bahan pembantu : bahan penggiat $=$ bahan pelunak

activator : Zn O, asam stearat

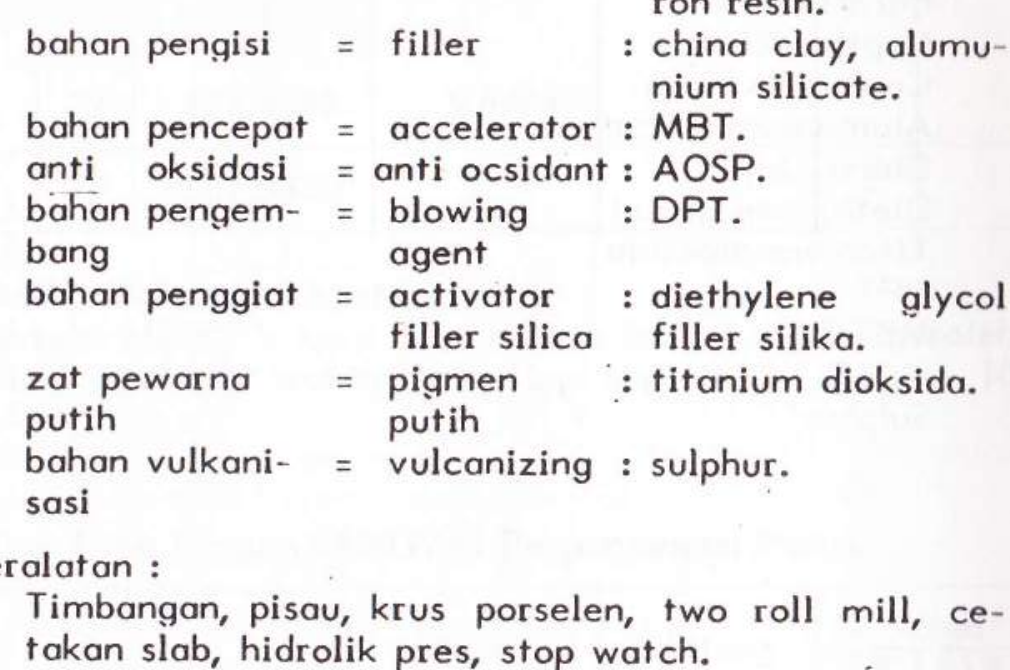

\section{B. Prosedur penelitian :}

Penelitian ini dibagi dalam dua tahap yaitu tahap pembuatan kompon sol mikroselluler dari tahap pengujian.

Tahap pembuatan kompon sol mikroselluler sesuai dengan formulasi bahan. Selanjutnya hasil pencampuran tersebut dilakukan pemasakan pendahuluan (precuring) dengan menggunakan hidrolik pres pada suhu $145^{\circ} \mathrm{C}$, tekanan $10 \mathrm{~kg} / \mathrm{cm}^{2}$ dan waktu bervariasi : 4, 6, 8, 10, menit untuk masing-masing formulasi. Kemudian dipost curing dengan menggunakan udara panas selama 30 menit pada suhu $130^{\circ} \mathrm{C}$. Tahap pengujian dilakukan terhadap sifat-sifat fisika kompon sol mikroselluler hasil penelitian dan pengujian secara mikros- 
kopis guna mengetahui homogenitas dari sel-sel udara da lam sol mikroselluler.

Hasil uji fisika dianalisa secara statistik dengan mengqunakan metoda faktorial.

C. Rancangan Penelitian :

Kompon sol mikroselluler dibuat dengan formulasi sebagai berikut :
Rubber Smoked sheet (RSS)
SBR
$\mathrm{ZnO}$
50 bagian
30 bagian
Asam stearat
Paraffin wax
5 bagian
3 bagian
2 bagian
Napthenic oil
2 bagian
5 bagian
Coumaron resin
40 bagian
20 bagian
1,5 bagian
4,5 bagian
Diethylene glycol
Titanium dioksida
DPT
MBT
AOSP
Sulphur
$3 ; 3,5 ; 4$ bagian
1,2 bagian
1 bagian
2,5 bagian

\section{HASIL PENELITIAN DAN PEMBAHASAN}

\section{Hasil Penelitian :}

Tabel 1 : Analisa Sidik Ragam (Anova) Tegangan Pitus.

\begin{tabular}{|c|c|c|c|c|c|c|}
\hline \multirow{2}{*}{ Sumber variasi } & \multirow{2}{*}{ dk } & \multirow{2}{*}{$\mathrm{jk}$} & \multirow{2}{*}{$R j k$} & \multirow{2}{*}{ F hitung } & \multicolumn{2}{|c|}{ F tabel } \\
\hline & & & & & $5 \%$ & \\
\hline Ulangan & 2 & 28,4527 & 14,2264 & - & - & - \\
\hline Perlakuan & 11 & 4423,1170 & - & - & - & - \\
\hline Blowing agent & 2 & 2241,3860 & 1120,6930 & $189,9673++$ & 3,44 & 5,72 \\
\hline Wkt precuring & 3 & 587,3593 & 195,7864 & $33,1875++$ & 3,05 & 4,82 \\
\hline Interaksi Blo- & 6 & 1594,3982 & 265,7330 & $45,0411++$ & 2,55 & 3,76 \\
\hline precuring & & & & & & \\
\hline Kekeliruan & 22 & 129,7868 & 5,8994 & - & - & - \\
\hline Total & 35 & 4581,3830 & - & - & - & - \\
\hline
\end{tabular}

++ ada perbedaan yang sangat nyata.

Dengan perhitungan MDRS $=r p \times S x$, dimana $S x=1,4023$ diperolel interaksi blowing agent $X$ waktu precuring terbaik 3,5 bagian 10 menit $\left(Y_{D}\right)$.

Tabel 2 : Analisa Sidik Ragam (ANOVA) Perpanjangan Putus.

\begin{tabular}{|c|c|c|c|c|c|c|}
\hline \multirow{2}{*}{ Sumber variasi } & \multirow{2}{*}{$d k$} & \multirow{2}{*}{$\mathrm{jk}$} & \multirow{2}{*}{$R j k$} & \multirow{2}{*}{ F hitung } & \multicolumn{2}{|c|}{$F^{\prime}$ tabel } \\
\hline & & & & & $5 \%$ & $1 \%$ \\
\hline Ulangan & 2 & 2997,1700 & 1498,5850 & - & - & - \\
\hline Perlakuan & 11 & 206496,0800 & - & - & - & - \\
\hline Blowing agent & 2 & 16297,1700 & 8148,5850 & $4,5275++$ & 3,44 & 5,72 \\
\hline Wkt precuring & 3 & 154036,3050 & 51345,4350 & $28,5285++$ & 3,05 & 4,82 \\
\hline Interaksi blw & 6 & 36162,6050 & 6027,1008 & $3,3488+$ & 2,55 & 3,76 \\
\hline $\begin{array}{l}\text { agent } X \text { wkt } \\
\text { precuring }\end{array}$ & & & & & & \\
\hline Kekeliruan & 22 & 39595,5000 & 1799,7955 & - & - & - \\
\hline Total & 35 & 249088,7500 & - & - & - & - \\
\hline
\end{tabular}


ada perbedaan yang nyata.

ada perbedaan yang sangat nyata.

engan perhitungan MDRS $=\mathrm{rp} \times \mathrm{Sx}_{\mathrm{x}}$, dimana $S_{x}=24,4935 \mathrm{di}$ eroleh interaksi blowing agent $X$ waktu precuring terbaik 3,5 agian 4 menit $\left(Y_{A}\right)$.

abel 3 : Analisa Sidik Ragam (ANOVA) Ketahanan Sobek.

\begin{tabular}{|c|c|c|c|c|c|c|}
\hline mber variasi & $\mathrm{dk}$ & jk & Rjk & $F$ hitung & $F+$ & abel \\
\hline & & & & 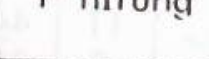 & $5 \%$ & $1 \%$ \\
\hline $\begin{array}{l}\text { angan } \\
\text { rlakuan } \\
\text { owing agent } \\
\text { kt precuring } \\
\text { eraksi Blo- } \\
\text { ng agent } \\
\text { precuring } \\
\text { keliruan }\end{array}$ & $\begin{array}{r}2 \\
11 \\
2 \\
3 \\
6\end{array}$ & $\begin{array}{r}- \\
681,7667 \\
6,2386 \\
126,5669 \\
548,9618 \\
122,6470\end{array}$ & $\begin{array}{c}5,4101 \\
- \\
3,1193 \\
42,1887 \\
91,4936\end{array}$ & $\begin{array}{l}0, \\
0,5595 \\
7,5676++ \\
16,4117++\end{array}$ & $\begin{array}{c}- \\
- \\
3,44 \\
3,05 \\
2,55\end{array}$ & $\begin{array}{c}- \\
- \\
5,72 \\
4,82 \\
3,76\end{array}$ \\
\hline tal & 35 & 815,2344 & - & - & - & - \\
\hline
\end{tabular}

ada perbedaan yang sangat nyata.

ngan perhitungan MDRS $=\mathrm{rp} \times \mathrm{S}_{\mathrm{x}}$, dimana $\mathrm{Sx}_{\mathrm{x}}=1,4023$ diperoleh eraksi blowing agent $X$ waktu precuring terbaik 3,5 bagian 10 me$\left(Y_{D}\right)$

bel 4 : Analisa Sidik Ragam (ANOVA) Perpanjangan Tetap.

\begin{tabular}{|c|c|c|c|c|c|c|}
\hline nber variasi & dk & jk & Rik & F hitung & $\mathrm{Ft}$ & abel \\
\hline & & & MJK & $r$ nitung & $5 \%$ & $1 \%$ \\
\hline $\begin{array}{l}\text { ngan } \\
\text { lakuan } \\
\text { wing agent } \\
\text { ctu precuring } \\
\text { raksi blowing } \\
\text { nt } X \text { wkt } \\
\text { curing } \\
\text { eliruan }\end{array}$ & $\begin{array}{r}2 \\
11 \\
2 \\
3 \\
6\end{array}$ & $\begin{array}{r}0,4369 \\
92,9173 \\
27,8401 \\
10,4291 \\
54,6481 \\
8,9096\end{array}$ & $\begin{array}{c}0,2185 \\
- \\
13,9201 \\
3,4764 \\
9,1080 \\
0,4049\end{array}$ & $\begin{array}{c}- \\
- \\
34,3791++ \\
8,5858++ \\
22,4944++\end{array}$ & $\begin{array}{c}- \\
- \\
3,44 \\
3,05 \\
2,55\end{array}$ & $\begin{array}{c}- \\
- \\
5,72 \\
4,82 \\
3,76\end{array}$ \\
\hline & 35 & 102,2611 & - & . & - & \\
\hline
\end{tabular}

++ ada perbedaan yang sangat nyata.

Dengan perhitungan MDRS $=r p \times S x$, dimana $S x=0,3674$ diperol interaksi blowing agent $X$ waktu precuring terbaik 3,5 bagian $10 \mathrm{~m}$ nit $\left(Y_{D}\right)$.

Tabel 5 : Analisa Sidik Ragam (ANOVA) Kekerasan

\begin{tabular}{|c|c|c|c|c|c|c|}
\hline \multirow{2}{*}{ Sumber variasi } & \multirow{2}{*}{ dk } & \multirow{2}{*}{ jk } & \multirow{2}{*}{ Rjk } & \multirow{2}{*}{ F hitung } & \multicolumn{2}{|c|}{ F tabel } \\
\hline & & & & & $5 \%$ & \\
\hline Ulangan & 2 & 0,5000 & 0,2500 & - & - & - \\
\hline Perlakuan & 11 & 125,6667 & - & - & - & - \\
\hline Blowing agent & 2 & 70,1667 & 35,0834 & $159,6878++$ & 3,44 & 5,7 \\
\hline Waktu precuring & 3 & 36,5556 & 12,1852 & $55,4629++$ & 3,05 & 4,8 \\
\hline $\begin{array}{l}\text { Interaksi blowing } \\
\text { agent } X \text { wkt } \\
\text { precuring }\end{array}$ & 6 & 18,9444 & 3,1574 & $14,3714++$ & 2,55 & - \\
\hline Kekeliruan & 22 & 4,8333 & 0,2197 & - & - & - \\
\hline
\end{tabular}

++ ada perbedaan yang sangat nyata.

Dengan perhitungan MDRS $=r p \times S x$, dimana $S x=0,2706$ diperol blowing agent $X$ waktu precuring 3 bdigian, 10 menit $\left(X_{D}\right)$.

Tabel 6 : Analisa Sidik Ragam (ANOVA) Bobot Jenis

\begin{tabular}{|c|c|c|c|c|c|c|}
\hline \multirow[t]{2}{*}{ Sumber variasi } & \multirow[t]{2}{*}{$\mathrm{dk}^{-}$} & \multirow{2}{*}{ jk } & \multirow{2}{*}{ Rjk } & \multirow{2}{*}{ F hitung } & \multicolumn{2}{|c|}{ F tabel } \\
\hline & & & & & $5 \%$ & $1 \%$ \\
\hline $\begin{array}{l}\text { Ulangan } \\
\text { Perlakuan } \\
\text { Blowing agent } \\
\text { Waktu precuring } \\
\text { Interaksi blowing } \\
\text { agent } X \text { wkt } \\
\text { precuring } \\
\text { Kekeliruan }\end{array}$ & $\begin{array}{r}2 \\
11 \\
2 \\
3 \\
6 \\
\\
22\end{array}$ & $\begin{array}{l}0,0003 \\
0,0280 \\
0,0003 \\
0,0010 \\
0,0150\end{array}$ & $\begin{array}{c}0,00015 \\
0,00015 \\
0,00033 \\
0,00250\end{array}$ & $\begin{array}{c}- \\
- \\
0,08772 \\
0,19300 \\
1,46200\end{array}$ & $\begin{array}{c}- \\
- \\
3,44 \\
3,05 \\
2,55\end{array}$ & $\begin{array}{r}- \\
5,7 \\
4,8 \\
3,7\end{array}$ \\
\hline Total & 35 & 0,0543 & - & - & - & - \\
\hline
\end{tabular}

Tidak terdapat perbedaan nyata, $F$ hitung $<F$ tabel $5 \%$, baik blowin agent, waktu precuring maupun interaksinya. 
abel 7 : Analisa Sidik Ragam (ANOVA) Ketahanan Kikis

\begin{tabular}{|c|c|c|c|c|c|c|}
\hline \multirow{2}{*}{ umber variasi } & \multirow{2}{*}{$d k$} & \multirow{2}{*}{$j k$} & \multirow{2}{*}{$R j k$} & \multirow{2}{*}{ F hitung } & \multicolumn{2}{|c|}{$F$ tabel } \\
\hline & & & & & $5 \%$ & $1 \%$ \\
\hline $\begin{array}{l}\text { langan } \\
\text { erlakuan } \\
\text { owing agent } \\
\text { aktu precuring } \\
\text { teraksi blowing } \\
\text { ent } X \text { wkt } \\
\text { ecuring } \\
\text { ekeliruan }\end{array}$ & $\begin{array}{r}2 \\
11 \\
2 \\
3 \\
6 \\
\\
22\end{array}$ & $\begin{array}{l}0,0395 \\
3,9618 \\
0,1177 \\
2,3683 \\
1,4758\end{array}$ & $\begin{array}{c}0,0198 \\
- \\
0,0589 \\
0,7894 \\
0,2460\end{array}$ & $\begin{array}{c}- \\
4,4621+ \\
59,8030++ \\
18,6364++\end{array}$ & $\begin{array}{c}- \\
- \\
3,44 \\
3,05 \\
2,55\end{array}$ & $\begin{array}{c}- \\
- \\
5,72 \\
4,82 \\
3,76\end{array}$ \\
\hline tal & 35 & 4,2917 & - & - & - & - \\
\hline
\end{tabular}

ada perbedaan yang nyata

ada perbedaan yang sangat nyata.

engan perhitungan MDRS $=\mathrm{rp} \times \mathrm{Sx}$, dimana $\mathrm{S} x=0,0663$ diperoleh reraksi blowing agent $X$ waktu precuring terbaik 3,5 bagian 6 me$\left(\mathrm{Y}_{\mathrm{B}}\right)$.

bel 8 : Analisa Sidik Ragam (ANOVA) Penyusutan

\begin{tabular}{|c|c|c|c|c|c|c|}
\hline \multirow{2}{*}{ mber variasi } & \multirow{2}{*}{$d k$} & \multirow{2}{*}{$j k$} & \multirow{2}{*}{$R j k$} & \multirow{2}{*}{ F hitung } & \multicolumn{2}{|c|}{$F$ tabel } \\
\hline & & & & & $5 \%$ & $1 \%$ \\
\hline $\begin{array}{l}\text { angan } \\
\text { rlakuan } \\
\text { wing agent } \\
\text { ktu precuring } \\
\text { eraksi blowing } \\
\text { ent } X \text { wkt } \\
\text { curing } \\
\text { keliruan }\end{array}$ & $\begin{array}{r}2 \\
11 \\
2 \\
3 \\
6\end{array}$ & $\begin{array}{l}0,0200 \\
5,5200 \\
1,7300 \\
2,5800 \\
1,2100 \\
0,1700\end{array}$ & $\begin{array}{r}0,0100 \\
0,8650 \\
0,8600 \\
0,2017\end{array}$ & $\begin{array}{c}- \\
- \\
98,2955++ \\
97,7273++ \\
22,9205++\end{array}$ & $\begin{array}{c}- \\
- \\
3,44 \\
3,05 \\
2,55\end{array}$ & $\begin{array}{c}- \\
- \\
5,72 \\
4,82 \\
3,76\end{array}$ \\
\hline & 35 & 5,7100 & - & - & - & - \\
\hline
\end{tabular}

ada perbedaan yang sangat nyata.

ngan perhitungan MDRS $=\mathrm{rp} \times \mathrm{Sx}$, dimana $S \mathrm{x}=0,0542$ diperoleh eraksi blowing agent $X$ waktu precuring terbaik 6 bagian 8 menit, agian 6 menit, 3 bagian 4 menif.
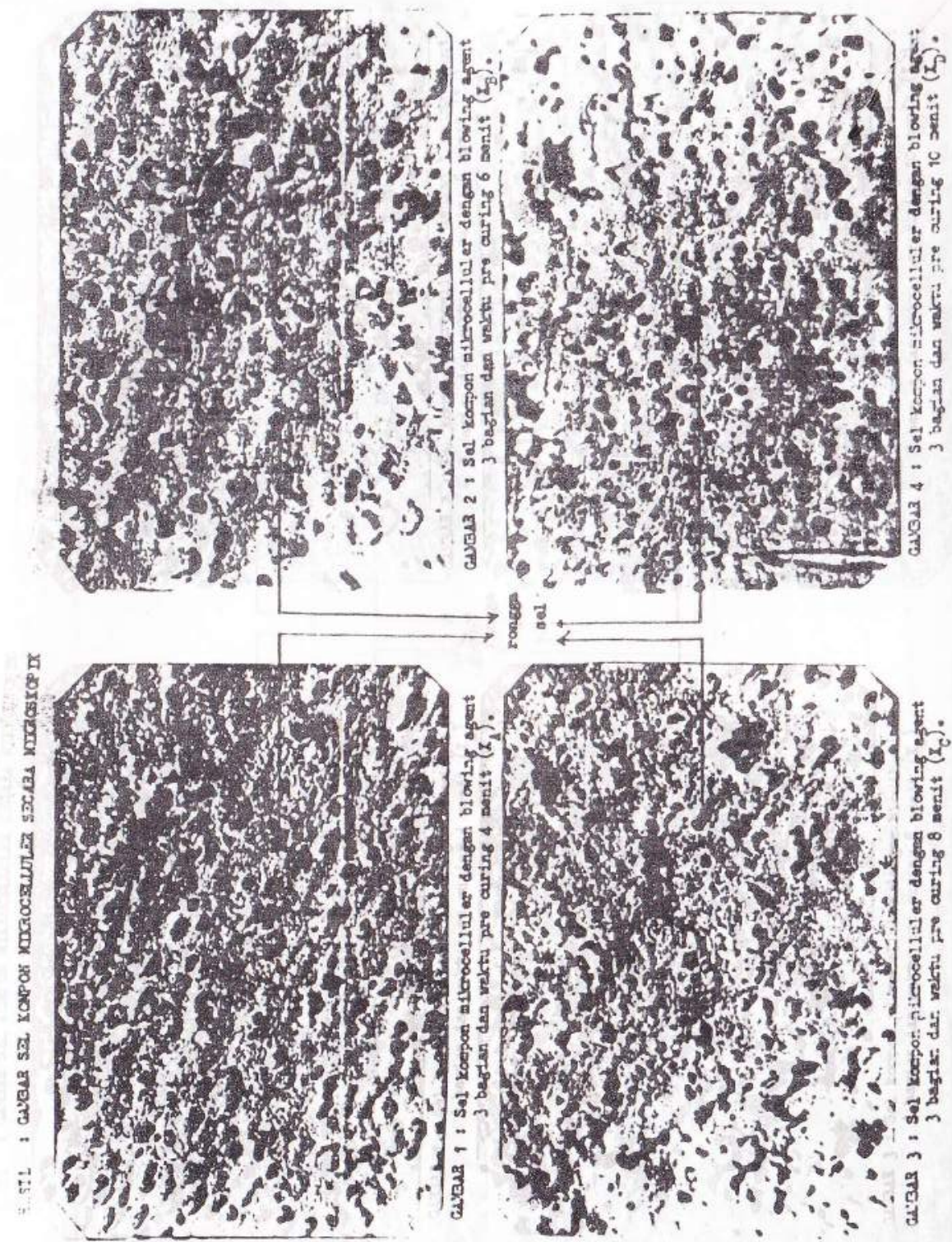

Majalah Barano Kulit Karot dan Deat 


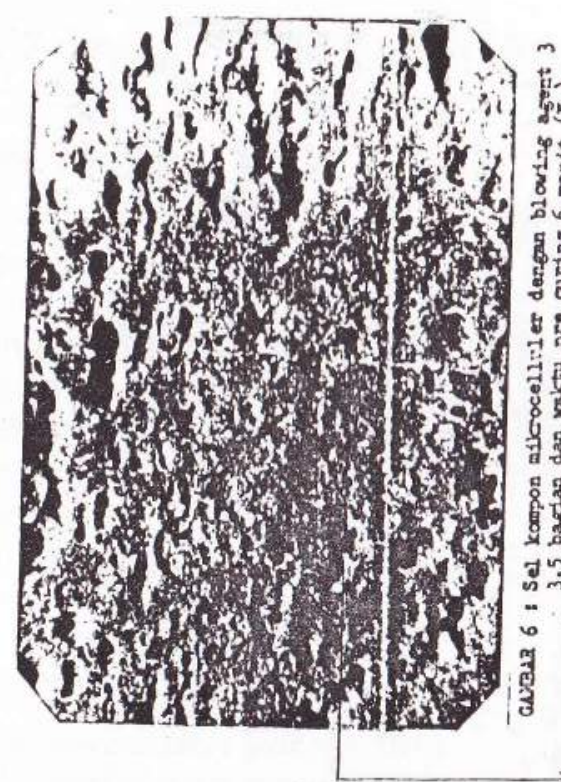

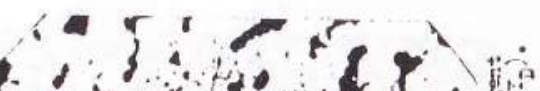

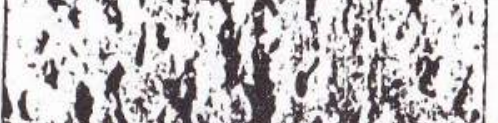

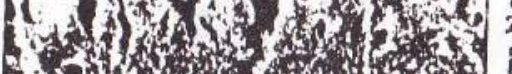

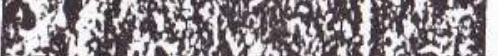
* 3120

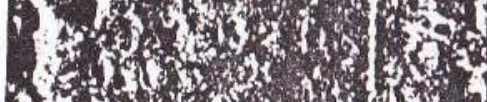

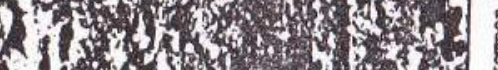

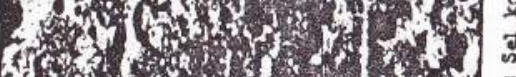
(1)
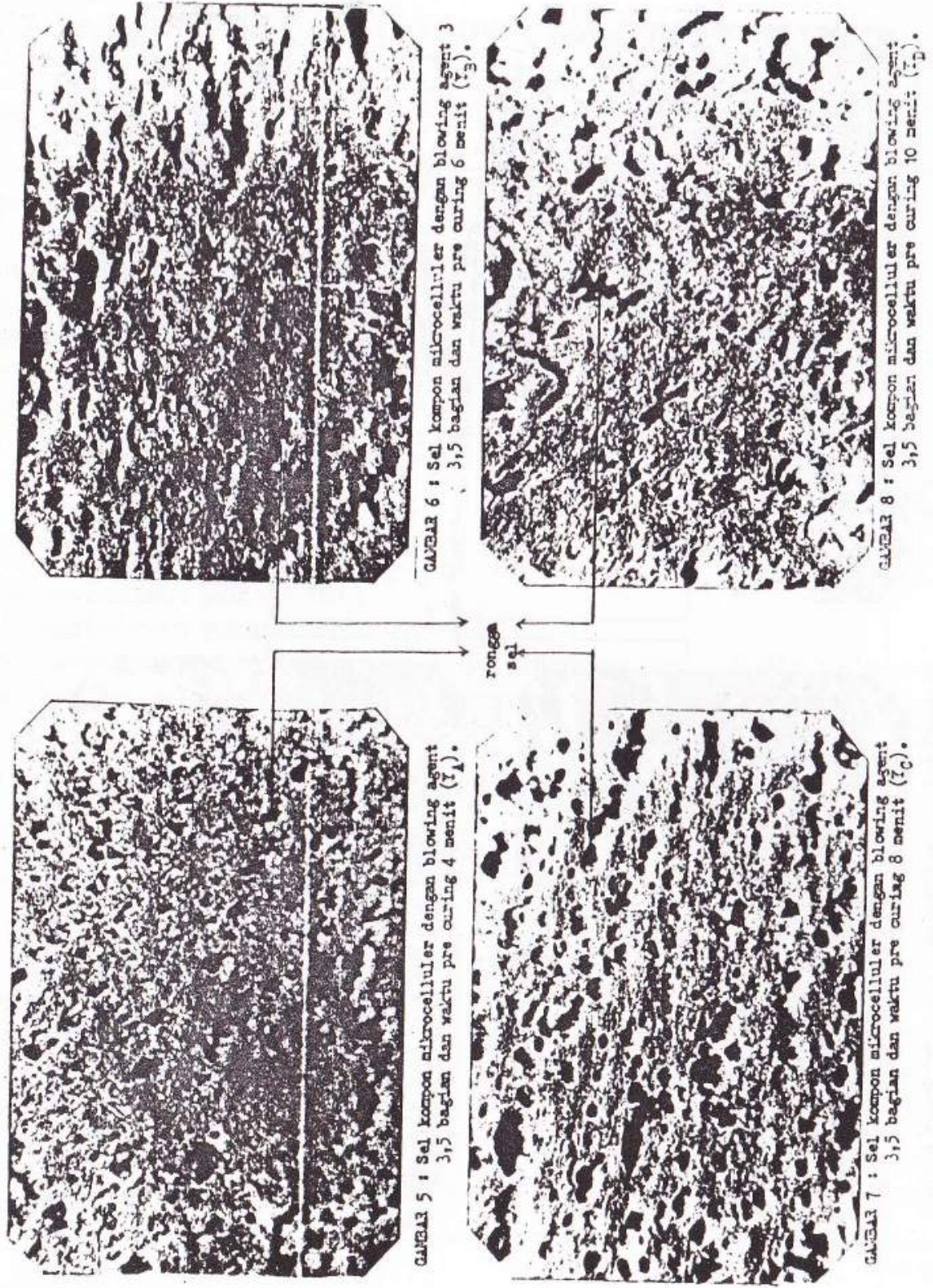

$\rightarrow$ है-

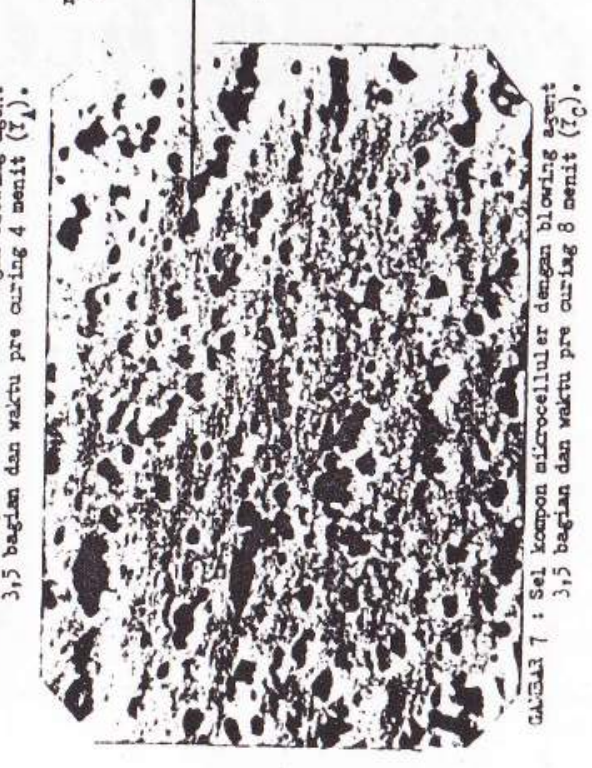

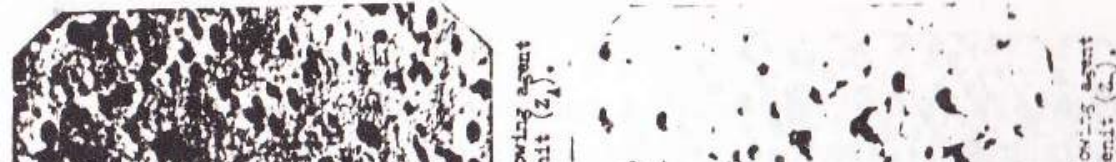

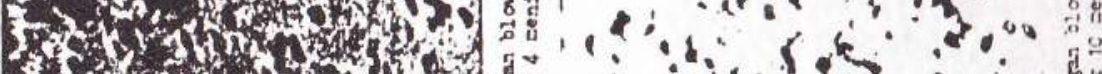

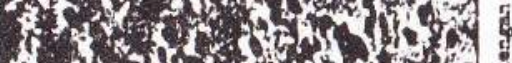

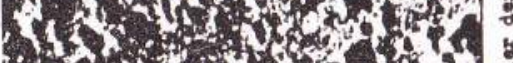

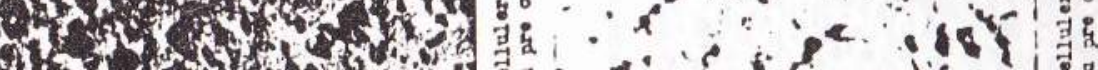

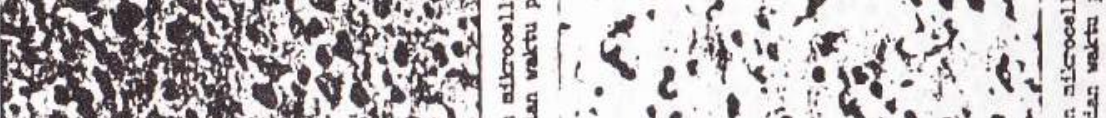

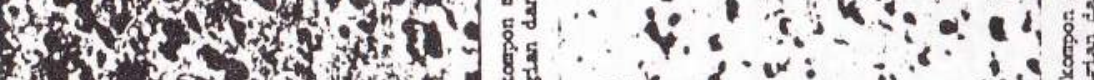

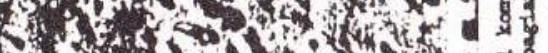

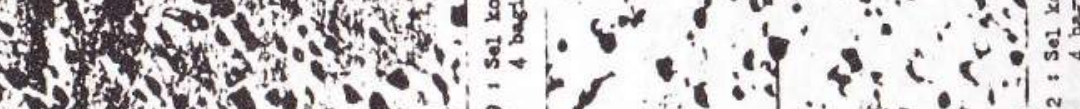
$7 x$ (1)

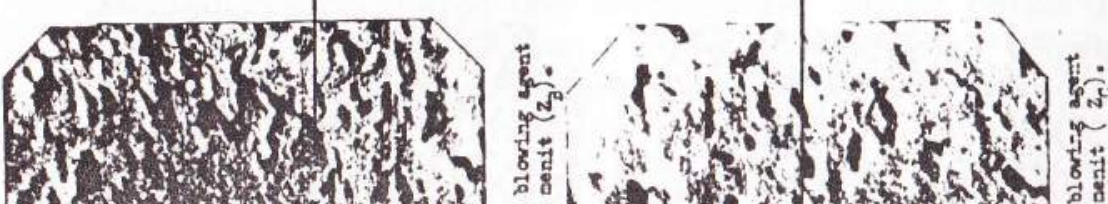

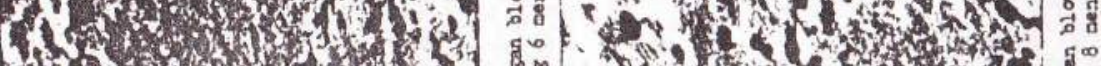

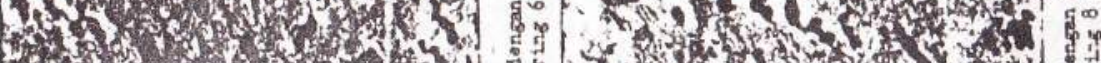

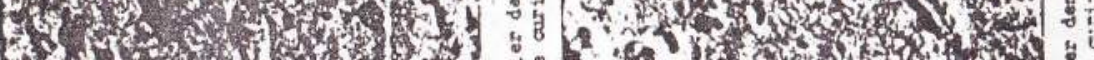

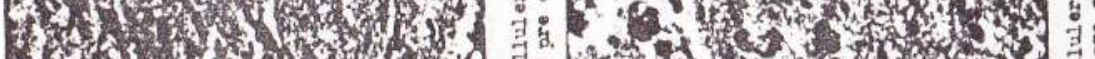
130

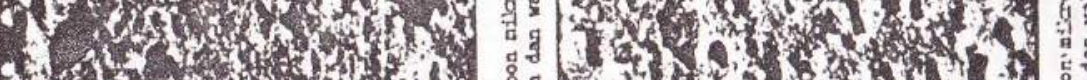

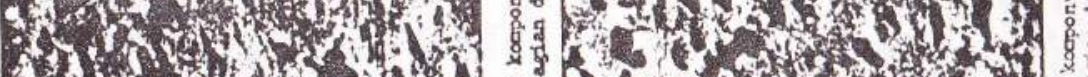

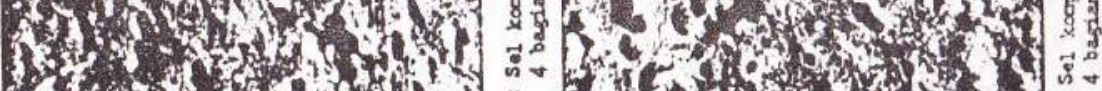

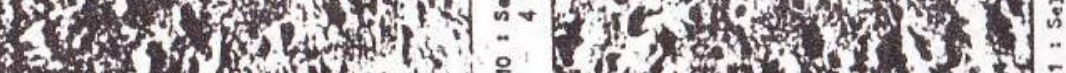

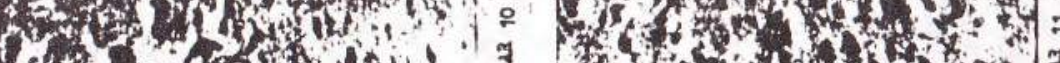
(4) 

putaran, sedang untuk kompon lain tidak retak pada
150.000 putaran.

9. Penyusutan (Skrinkage):

Kompon dengan blowing agent 3 bagian waktu precuring 4, 6, 8 menit tidak terjadi penyusutan, sedang kompon yang lainnya terjadi penyusutan.

Penyusutan tertingai terjadi pada kompon dengan blowing agent 4 bagian, waktu precuring 10 menit.

10. Gambar sel kompon mikroselluler secara mikroskopik : Ternyata kompon hasil penelitian homogenitasnya kompon sama dengan antara yang satu dengan yana lain, teprecuring 10 dengan blowing agent 4 bagian dan waktu saran, sel-sel menit paling homogen., sedang kompon panaan kempel udaranya lebih banyak jika dibanding depasaran lebih banyak penelitian, hal ini disebabkan kompon pasaran lebih banyak mengqunakan blowing agent.

\section{KESIMPULAN}

Dari hasil penelitian dapat disimpulkan sebagai berikut :

1. Dilihat dari faktor-faktor uji fisika tegangan putus, perpanjangan putus, ketahanan sobek, perpanjangan tetap, kekerasan, ketahanan retak lentur penyusutan, maka blowing agent yang terbaik adalah 3,5 bagian dan waktu precuring
nya 6 menit.

2. Bobot jenis tidak dipengaruhi oleh faktor blowing agent waktu precuring maupun interaksinya.

\section{DAFTAR PUSTAKA}

I. ANONIMOUS

: "Rubber Technology and Manufacture SBP Board of Consultant and Engineners

2. HARRY BARRON: "Modern Rubber Chemistry", D. Van Nos trand Company Inc 1948, NEW YORK USA.

3. Ir. SOENTOYO : "Experimental Design".

Universitas Brawijaya, MALANG.
4. SOEWARTI SOESENO

5. T. KUSNATA
: "Pedoman Pengujian Sifat Fisika Barang Jadi Karet".

Menara Perkebunan 153 - 205.47 - 1979

: "Pengujian Fisika pada Karet". Balai Penelitian Perkebunan Bogor. 